\title{
PENGARUH KUALITAS PELAYANAN DAN KARAKTERISTIK SOSIODEMOGRAFI TERHADAP MINAT KUNJUNGAN ULANG YANG DIMODERASI OLEH KEPUASAN PASIEN PADA PELAYANAN RAWAT JALAN PUSKESMAS KEDUNGBANTENG KABUPATEN BANYUMAS
}

\author{
Firman Guswaman ${ }^{1 *}$, Haryadi ${ }^{1}$, Eman Sutrisna ${ }^{2}$ \\ ${ }^{1}$ Program Pascasarjana Magister Manajemen Universitas Jenderal Soedirman Purwokerto \\ ${ }^{2}$ Fakultas Kedokteran Universitas Jenderal Soedirman Purwokerto \\ ${ }^{*}$ Email corresponding author: guswaman@gmail.com
}

\begin{abstract}
Abstrak
Penelitian ini merupakan penelitian survey pada pasien rawat jalan di Puskesmas Kedungbanteng, Kabupaten Banyumas. Tujuan dari penelitian ini yaitu untuk mengetahui pengaruh kualitas pelayanan dan karakteristik sosiodemografi (jenis kelamin, usia, tingkat pendidikan, penghasilan dan jarak tempuh) terhadap minat kunjungan ulang yang dimoderasi oleh kepuasan pasien. Jumlah responden yang diambil dalam penelitian ini yaitu sebanyak 97 responden. Metode purposive sampling digunakan dalam penentuan responden. Analisis data menggunakan uji validitas dan reliabilitas, uji asumsi klasik, uji t, uji $\mathrm{f}$ dan uji Multiple Regression Analysis. Berdasarkan hasil penelitian dan analisis data dengan menggunakan SPSS menunjukkan bahwa: (1) Kualitas pelayanan berpengaruh positif terhadap minat kunjungan ulang, (2) Jenis kelamin tidak berpengaruh terhadap minat kunjungan ulang, (3) Usia berpengaruh negatif terhadap minat kunjungan ulang, (4) Tingkat pendidikan berpengaruh negatif terhadap minat kunjungan ulang, (5) Pendapatan berpengaruh positif terhadap minat kunjungan ulang, (6) Jarak tempuh tidak berpengaruh terhadap minat kunjungan ulang, (7) Kepuasan pasien hanya dapat memoderasi jarak tempuh terhadap minat kunjungan ulang pasien.
\end{abstract}

Kata Kunci: Kualitas Pelayanan, Sosiodemografi, Kepuasan, Kunjungan Ulang

\begin{abstract}
This study is a survey research in outpatients of Kedungbanteng Health Center, Banyumas Regency. The purpose of this study is to determine the effect of service quality and sociodemographic characteristics (gender, age, education level, income and distance) on the interest in revisiting which was moderated by patient satisfaction. The number of respondents taken in this study are 97 respondents. The purposive sampling method is used in determining respondents. Analysis of the data used are validity and reliability test, classic assumption test, $\mathrm{t}$ test, $\mathrm{f}$ test, and Multiplle Regression Analysis. Based on the results of research and data analysis using SPSS, it shows that: (1) Service quality has a positive effect on interest in revisiting, (2) Gender has no effect on interest in repeat revisiting, (3) Age has a negative effect on interest in revisiting, (4) Education level has a negative effect on interest in revisiting, (5) Income has a positive effect on interest in revisiting, (6) Distance has no effect on interest in revisiting, (7) Patient satisfaction can only moderate the distance to interest in patient revisiting.
\end{abstract}

Keywords: Service Quality, Sociodemography, Satisfaction, Revisiting

\section{PENDAHULUAN}

Pelayanan kesehatan yang baik dapat terjadi apabila pelayanan tersebut memiliki kualitas yang tinggi, aman, serta efektif bagi masyarakat pengguna layanan tersebut. Upaya pembangunan kesehatan dapat berhasil jika kebutuhan sumberdaya kesehatan dapat terpenuhi. Sehingga untuk tercapainya pengelolaan pelayanan kesehatan yang berkualitas ini pihak pelayanan kesehatan harus dapat memenuhi persyaratan mencakup ketersediaan, kewajaran, berkesinambungan, dapat diterima, dapat dijangkau, efisien dan bermutu (WHO, 2006). 
Pengaruh Kualitas Pelayanan dan Karakteristik Sosiodemografi Terhadap Minat Kunjungan Ulang yang Dimoderasi Oleh Kepuasan Pasien Pada Pelayanan Rawat Jalan Puskesmas Kedungbanteng Kabupaten Banyumas

Keputusan Menteri Pendayagunaan Aparatur Negara No. KEP/25/M.PAN/2004 tentang Pedoman Umum Penyusunan Indeks Kepuasan Masyarakat Unit Pelayanan Instansi Pemerintah, menginstruksikan agar setiap penyelenggara pelayanan melakukan survey kepuasan secara berkala untuk mengetahui tingkat kinerja unit pelayanan di lingkungan instansinya.Kepuasan pelanggan adalah evaluasi pasca pembelian dengan penilaian persepsi apakah produk atau jasa tersebut memenuhi harapan atau tidak memenuhi harapan pra pembelian (Umar, 2003). Beberapa faktor yang dapat menentukan kepuasan pasien diantaranya adalah adanya kesembuhan, mutu pelayanan petugas yang baik, ramah, santun serta sarana prasarana yang lengkap (Azwar,1996).

Menurut profil kesehatan Kabupaten Banyumas, data kunjungan pasien rawat jalan Puskesmas di Kabupaten Banyumas berturut-turut dari tahun 2013-2015 yaitu 593.401 orang, 1.025.103 orang, dan 1.227.664 orang. Hampir seluruh Puskesmas di Kabupaten Banyumas mengalami kenaikan kunjungan pasien rawat jalan kecuali Puskesmas Kedungbanteng. Data kunjungan pasien rawat jalan Puskesmas Kedungbanteng dari tahun 2013-2015 yaitu 40.765 orang, 35.579 orang, dan 34.461 orang. Salah satu faktor yang mempengaruhi penurunan kunjungan pasien ini diantaranya karena adanya penurunan kualitas pelayanan di Puskesmas Kedungbanteng. Kenaikan jumlah kunjungan pasien terjadi pada tahun 2016 dan 2017,yaitu 55.860 orang dan 60.742 orang. Pada tahun 2016 Puskesmas Kedungbanteng mendapatkan akreditasi utama sehingga berdampak pada kualitas pelayanan yang semakin membaik dan kunjungan pasien yang meningkat.

Kenaikan jumlah kunjungan pasien pada tahun 2016 dan 2017 menandakan adanya peningkatan kualitas pelayanan yang sangat baik sehingga harus dipertahankan supaya jumlah kunjungan di tahun-tahun berikutnya tetap stabil. Semakin baik kualitas pelayanan maka pasien semakin puas dan ingin berkunjung kembali ke Puskesmas jika mereka sakit. Puskesmas Kedungbanteng memiliki sistem kotak saran yang diletakan di ruang tunggu pelayanan, namun semenjak tahun 2016 kotak saran selalu kosong sehingga petugas jarang untuk mengecek kembali kotak tersebut, padahal hal ini sangat berguna untuk mengetahui tingkat kepuasan pasien terhadap pelayanan di Puskesmas. Kepuasan dan ketidakpuasan terhadap suatu pelayanan kesehatan juga dapat mempengaruhi perilaku pasien selanjutnya. Jika pasien puas, ia akan menunjukkan kemungkinan yang lebih tinggi untuk kembali menggunakan jasa pelayanan tersebut. Sebaliknya jika pasien merasa tidak puas, pasien akan behenti menggunakan jasa dan menceritakan pengalaman buruknya kepada rekan-rekannya (Kotler, 2009; Hartono, 2010).

Disamping faktor yang berhubungan dengan manajemen pelayanan kesehatan, kepuasan pasien juga dapat dipengaruhi oleh karakteristik sosiodemografi pasien itu sendiri. Meskipun kualitas pelayanan dan dengan kasus penyakit yang sama tingkat kepuasan yang dirasakan pasien dapat berbeda-berbeda. Hal ini tergantung kepada latar belakang sosiodemografi pasien seperti usia, jenis kelamin, tingkat pendidikan, pendapatan, dan jarak tempuh pasien (Sarwono,1996). Banyaknya masyarakat dengan tingkat pendidikan yang rendah dan acuh terhadap kesehatan membuat para petugas kesulitan dalam kegiatan promosi kesehatan sehingga membuat tingkat kesakitan meninggi. Selain itu demografi Kecamatan Kedungbanteng 80\% merupakan wilayah pegunungan sehingga membuat akses warga menuju puskesmas menjadi sedikit terhambat.

Berdasarkan fenomena tersebut, peneliti tertarik untuk mengetahui hubungan antara kualitas pelayanan, usia, jenis kelamin, tingkat pendidikan, pendapatan dan jarak tempuh terhadap kujungan ulang yang dimoderasi oleh kepuasan pasien dalam pelayanan rawat jalan di Puskesmas Kedungbanteng Kabupaten Banyumas. 


\section{TINJAUAN PUSTAKA}

\section{Kepuasan Pelanggan}

Menurut Oliver dalam Umar (2003) kepuasan pelanggan adalah evaluasi pasca pembelian dengan penilaian persepsi apakah produk atau jasa tersebut memenuhi harapan atau tidak memenuhi harapan pra pembelian. Gaperz (2003) menyatakan bahwa pelanggan yang merasa puas adalah pelanggan yang mendapatkan nilai tambah lebih dari penyedia layanan jasa. Apabila pelanggan merasa tidak puas terhadap suatu pelayanan yang diberikan, maka pelayanan tersebut akan menjadi tidak efektif dan tidak efisien.

Perusahaan penyedia layanan jasa yang menjunjung tinggi kepuasan pelanggan akan memperoleh beberapa manfaat bagi keberlangsungan layanan mereka. Menurut Lovelock dalam Almana, dkk. (2018) tingkat kepuasan pelanggan dalam jangka panjang sangat menguntungkan bagi perusahaan karena mempertahankan pelanggan lebih baik daripada mencari pelanggan baru untuk menggantikan pelanggan lama. Pelanggan yang puas akan menjadi iklan berjalan bagi perusahaan sehingga dapat menurunkan biaya promosi untuk menarik pelanggan baru.

Menurut Rambat dan Hamdani (2001), kepuasan pelanggan dapat dipengaruhi oleh faktor-faktor seperti kualitas produk, kualitas pelayanan, emosional, dan biaya. Sedangkan faktor-faktor lain yang dapat mempengaruhi kepuasan pelanggan menurut Kanignaat dan Chaipoopirutina (2014) yaitu relational performance, operational performance, cost performance, dan organization performance.

\section{Kualitas Pelayanan}

Kualitas secara umum adalah penilaian karakteristik suatu produk atau jasa berupa performa, kehandalan, mudah digunakan, estetis, dan lain-lain. Sedangkan arti kualitas secara strategis yaitu keinginan atau kebutuhan pelanggan yang terpenuhi oleh perusahaan (Gasperz, 1997). Menurut Kotler dalam Alma (2007), kualitas pelayanan adalah proses perbaikan mutu secara berkala pada produk atau jasa yang dilakukan oleh perusahaan. Sedangkan menurut Tjiptono (2007), suatu upaya dalam mengimbangi harapan pelanggan dengan memenuhi segala kebutuhan dan keinginannya dengan penyampaian yang tepat.

Kualitas pelayanan haruslah dilihat dari sudut pandang penilaian pengguna jasa layanan, sehingga perusahaan harus berorientasi pada kepentingan pelanggan dalam rumusa strategi dan program layanannya. Kualitas pelayanan yang jauh dari harapan pelanggan dapat menimbulkan hilangnya minat pembelian di masa yang akan datang. Sebaliknya, jika perusahaan memberikan kualitas yang sesuai atau melebihi harapan pelanggan otomatis dapat menaikan minat pembelian ulang dari pelanggan (Dharmawan, 2013).

Suatu bisnis dapat dikatakan berhasil jika memiliki kualitas pelayanan yang baik. Dengan demikian, kualitas pelayanan memiliki beberapa manfaat untuk kesuksesan bisnis tersebut. Manfaat-manfaat kualitas pelayanan menurut Bilson (2001) yaitu; (1) penetapan harga premium dapat dilakukan jika pelayanan yang diberikan istimewa atau sangat memuaskan. Pelanggan yang terpuaskan tidak akan mempermasalahkan biaya meskipun perusahaan menetapkan harga yang tinggi, (2) adanya peluang untuk diversifikasi produk, (3) terciptanya loyalitas pelanggan, (4) penghematan biaya-biaya seperti biaya promosi, biaya perbaikan kesalahan, biaya membangun citra perusahaan karena wanprestasi dan lain-lain serta, (5) menciptakan kepuasan kerja pada karyawan perusahaan.

Menurut Zeithaml, dkk. (2000) terdapat 10 faktor yang dapat mempengaruhi kualitas pelayanan, diantaranya yaitu: Reliability (terdiri dari performa kerja karyawan dan kemampuan untuk dipercaya oleh pelangga), Responsiveness (merupakan kesigapan karyawan dalam memberikan 
Pengaruh Kualitas Pelayanan dan Karakteristik Sosiodemografi Terhadap Minat Kunjungan Ulang yang Dimoderasi Oleh Kepuasan Pasien Pada Pelayanan Rawat Jalan Puskesmas Kedungbanteng Kabupaten Banyumas

pelayanan terhadap pelanggan), Competence (merupakan kemampuan (pengetahuan dan keterampilan) karyawan yang diperlukan dalam pelayanan terhadap pelanggan), Acces (merupakan kemudahan dan terjangkaunya lokasi pelayanan untuk dikunjungi oleh pelanggan), Courtesy (merupakan sikap ramah yang dimiliki oleh karyawan), Communication (merupakan tata cara pemberian informasi dengan bahasa yang mudah dimengerti kepada pelanggan), Credibility (merupakan perusahaan memiliki sifat jujur dan dapat dipercaya sehingga interaksi dengan pelanggan tercipta secara harmonis), Security (merupakan faktor keamanan perusahaan yang terdiri dari keamanan fisik, finansial maupun kerahasiaan perusahaan), Understanding (merupakan pemahaman kebutuhan pelanggan yang dilakukan oleh perusahaan) dan Tangibles (merupakan bukti fisik perusahaan seperti fasilitas, peralatan, dan representasi fisik pelayanan jasa.

\section{Karakteristik Sosiodemografi}

Usia adalah keadaan kehidupan seseorang yang dilihat dari segi kronologis dengan adanya perkembangan baik secara anatomis maupun fisiologisnya dan diukur dalam satuan waktu (Nuswantari, 1998). Tingkat kematangan tindakan seseorang dapat ditentukan oleh usia. Salah satu tindakan yang dipengaruhi oleh usia adalah dalam memberikan keluhan terhadap suatu produk atau jasa yang tidak sesuai dengan harapan. Beberapa penelitian juga menyebutkan bahwa usia perilaku keluhan konsumen memiliki hubungan yang signifikan dengan usia (Ngai dkk, 2007; Phau dan Biard, 2008; Yulianti dan Anzola, 2009).

Jenis kelamin adalah perbedaan antara laki-laki dan perempuan dari ciri anatomis maupun fisiologisnya. Jenis kelamin adalah faktor penting dalam hak, tanggungjawab dan menentukan peran serta merupakan bagian dari sistem sosial. Jenis kelamin atau gender dibentuk dari perilaku seperti tanggung jawab, sikap, penampilan dan kepribadian (Wade dan Tavris, 2007).

Menurut Nurkholis (2013) pendidikan adalah upaya yang dilakukan untuk membantu manusia dalam perkembangan menuju kedewasaan, baik secara langsung maupun tidak langsung. Selain sebagai transfer ilmu dan keahlian, pendidikan lebih bersifat membentuk kesadaran dan kepribadian individu maupun masyarakat. Nilai-nilai seperti cara berpikir dan persepsi terhadap suatu masalah dapat dipengaruhi oleh tingkat pendidikannya. Dalam segi ekonomi, informasi akan lebih responsif jika pelanggan memiliki pendidikan yang tinggi. Perilaku konsumen dalam pemilihan suatu produk atau jasa juga dapat dipengaruhi oleh tingkat pendidikan, sehingga dengan tingkat pendidikan yang berbeda dapat mengakibatkan perbedaan dalam selera pelanggan juga (Sumarwan, 2002).

Pendapatan adalah bayaran atau kompensasi yang diterima seseorang setelah dia melakukan pekerjaannya. Pendapatan merupakan sumber material yang sangat penting bagi seseorang sehingga dia bisa membiayai kebutuhan konsumsinya. Pendapatan juga dapat memperlihatkan seberapa besar daya beli seseorang, sehingga daya beli seseorang yang pendapatannya kecil akan lebih sedikit daripada dengan yang pendapatannya besar (Sumarwan, 2002).

Jarak adalah suatu pembatas alami yang terbagi menjadi dua macam, yaitu jarak absolut dan jarak relatif. Jarak absolut adalah jarak dua lokasi yang bisa diperhatikan dengan skala peta dan diukur berdasarkan garis lurus diudara. Jarak relatif adalah jarak tempuh perjalanan yang dibutuhkan dari titik awal ke titik akhir dengan memperhatikan waktu atau biaya perjalanan dan bersifat tidak tetap (Damanik dkk., 2006).

\section{Kunjungan Ulang Pasien}

Kunjungan atau pembelian ulang merupakan konsep penting dalam bidang pemasaran dan loyalitas pelanggan. Pelanggan akan melakukan pembelian ulang berdasarkan pengalaman 
mereka yang terpuaskan setelah melakukan pembelian suatu produk atau jasa (Kotler, 2009; Hartono, 2010; Li, 2010). Minat kunjungan ulang pasien sangat dipengaruhi oleh pengalaman yang diirasakannya saat pertama kali berkunjung, sehingga kualitas pelayanan yang baik dapat menarik pasien untuk datang kembali tempat pelayanan kesehatan tersebut karena harapan mereka sudah terpuaskan sehingga apabila suatu saat nanti ketika mereka membutuhkannya lagi. Sebaliknya, apabila pasien tidak terpuaskan maka tidak menutup kemungkinan pasien tersebut untuk mengajukan keluhan, menggugat, bahkan tidak akan melakukan kunjungan ulang di pelayanan kesehatan tersebut (Hidajati, 2009; Kotler, 2009; Hartono, 2010; Li, 2010).

Menurut Labeouf dalam Karyati (2006) seorang pelanggan yang tidak berkunjung kembali untuk membeli produk atau jasa dapat disebabkan oleh beberapa faktor. Faktor-faktor tersebut diantaranya yaitu; (1) pelanggan sudah meninggal dunia, (2) pelanggan pindah tempat sehingga jauh dari perusahaan tersebut, (3) pelanggan melakukan transaksi jual beli dengan perusahaan lain, (4) pelanggan terbujuk pesaing untuk bertransaksi di tempatnya, (5) pelanggan tidak terpuaskan oleh produk atau jasa yang diterimanya dari perusahaan tersebut dan (6) Pelanggan merasa tidak nyaman dengan kualitas pelayanan yang buruk.

\section{METODE PENELITIAN}

Penelitian ini menggunakan pendekatan penelitian kuantitatif untuk mengetahui pengaruh kualitas pelayanan, dan karakteristik sosiodemografi terhadap minat kunjungan ulang yang dimoderasi oleh kepuasan pasien dalam pelayanan rawat jalan di Puskesmas Kedungbanteng Kabupaten Banyumas. Penelitian yang digunakan adalah penelitian lapangan atau field research untuk mengetahui tanggapan dari responden secara langsung. Penelitian ini tidak memberikan perlakuan pada subjek penelitian tetapi hanya mengkaji fakta yang ada

Populasi pada penelitian ini adalah seluruh masyarakat umum yang berobat rawat jalan di Puskesmas Kedungbanteng Kabupaten Banyumas. Untuk mengetahui seberapa banyak sampel minimal yang mewakili populasi pasien rawat jalan di Puskesmas Kedungbanteng Kabupaten Banyumas maka digunakan metode interval taksiran (Umar,2003). Metode ini digunakan apabila populasinya tidak dapat diukur ketepatan jumlahnya, dengan rumus sebagai berikut:

\section{$\mathbf{n} \geq \mathbf{p q}\left(\mathrm{Z}_{\alpha / 2} / \mathbf{e}\right)^{2}$}

Keterangan:

$\mathrm{n} \quad=$ ukuran sampel

$\mathrm{Z}_{\alpha / 2} \quad=$ nilai $\mathrm{Z}$ tabel

e = persentase kelonggaran ketidaktelitian karena kesalahan pengambilan sampel yang masih dapat ditolerir. Dalam penelitian ini batas kelonggaran yang dipakai adalah $10 \%$.

$\mathrm{p} \& \mathrm{q}=$ probabilitas $(\mathrm{p}=0,5 ; \mathrm{q}=0,5)$

Dari rumus diatas dapat dihitung jumlah sampel sebagai berikut:

$\mathbf{n} \geq \mathbf{p q}\left(\mathrm{Z}_{\boldsymbol{\alpha} / \mathbf{2}} / \mathbf{e}\right)^{\mathbf{2}}$

$\mathrm{n} \geq 0,5 \times 0,5(1,96 / 0,1)^{2}$

$\mathrm{n} \geq 96,04$

Berdasarkan rumus tersebut, didapatkan jumlah sampel pada penelitian ini adalah 96,04. Hasil ini dibulatkan menjadi 97, sehingga pada penelitian ini akan meneliti 97 responden. Metode pemilihan sampel pada penelitian ini menggunakan teknik purposive sampling yaitu peneliti mengumpulkan data dari subjek yang berdasarkan atas pertimbangan tertentu dengan tujuan 
Pengaruh Kualitas Pelayanan dan Karakteristik Sosiodemografi Terhadap Minat Kunjungan Ulang yang Dimoderasi Oleh Kepuasan Pasien Pada Pelayanan Rawat Jalan Puskesmas Kedungbanteng Kabupaten Banyumas

supaya data yang diperoleh lebih representatif (Sugiyono, 2012). Kriteria inklusi dalam penelitian ini yaitu (1) pasien atau pengantar pasien yang sedang berobat jalan di Puskesmas Kedungbanteng dan (2) pasien memakai BPJS atau asuransi kesehatan lainnya. Sedangkan kriteria eksklusi dalam penelitian ini yaitu (1) pasien yang sedang melakukan perawatan berkala sesuai rekomendasi dokter dan (2) pasien umum dengan pembayaran menggunakan uang pribadi.

Metode pengambilan data dilakukan dengan metode survey. Metode survey yang digunakan merupakan metode survey individu, yaitu dengan menemui secara langsung. Alat pengumpulan data yang digunakan adalah kuesioner. Kuesioner berupa pertanyaan tertutup berkaitan dengan faktor mengenai kualitas pelayanan, sistem pembiayaan, usia, jenis kelamin, pendidikan, dan pendapatan terhadap minat kunjung ulang yang dimoderasi oleh kepuasan pasien dalam pelayanan rawat jalan di Puskesmas Kedungbanteng Kabupaten Banyumas.

Teknik analisis data yang digunakan dalam penelitian ini adalah dengan metode Moderated Regression Analysis (MRA) yang bertujuan untuk menguji pengaruh interaksi dari variabel moderasi. Uji f digunakan untuk mengetahui tingkat signifikansi secara bersama-sama pengaruh variabel independen terhadap variabel dependen. Sedangkan uji t digunakan untuk menguji tingkat signifikasi secara parsial apakah masing-masing variabel independen berpengaruh terhadap dependen.

\section{HASIL DAN PEMBAHASAN}

\section{Deskripsi Hasil Penelitian}

Responden pada penelitian ini terdiri dari 33 orang laki-laki dan 64 orang perempuan dengan kelompok usia paling banyak yaitu pada kelompok usia 46-55 tahun sebanyak 23 orang, sedangkan untuk kelompok usia paling sedikit yaitu pada usia kurang dari 26 tahun sebanyak 10 orang.

Tabel 1. Frekuensi Jenis Kelamin

\begin{tabular}{lcc}
\hline Jenis Kelamin & Frekuensi & $\begin{array}{c}\text { Persentase } \\
(\%)\end{array}$ \\
\hline Laki-Laki & 33 & $34 \%$ \\
Perempuan & 64 & $68 \%$ \\
\hline Total & 97 & $100 \%$ \\
\hline
\end{tabular}

Tabel 2. Frekuensi Kelompok Usia

\begin{tabular}{lcc}
\hline \multicolumn{1}{c}{ Usia } & Frekuensi & Persentase(\%) \\
\hline$<26$ Tahun & 10 & $10,30 \%$ \\
26-35 Tahun & 16 & $16,50 \%$ \\
36-45 Tahun & 19 & $19,60 \%$ \\
46-55 Tahun & 23 & $23,70 \%$ \\
56-65 Tahun & 16 & $16,50 \%$ \\
$>65$ Tahun & 13 & $13,40 \%$ \\
\hline Total & 97 & $100 \%$ \\
\hline
\end{tabular}

Tingkat pendidikan responden paling banyak yaitu pada lulusan SMA/sederajat sebanyak 39 orang, sedangkan tingkat pendidikan paling sedikit yaitu pada lulusan perguruan tinggi sebanyak 
2 orang. Kelompok penghasilan paling banyak yaitu pada kelompok penghasilan 1,1-2 juta sebanyak 44 orang, sedangkan kelompok penghasilan paling sedikit yaitu pada kelompok penghasilan $<500$ ribu sebanyak 9 orang. Jarak tempuh responden yang paling banyak yaitu jarak dekat sebanyak 40 orang, sedangkan jarak tempuh responden yang paling sedikit yaitu sangat jauh sebanyak 9 orang.

Tabel 3. Frekuensi Tingkat Pendidikan

\begin{tabular}{lcc}
\hline \multicolumn{1}{r}{ Pendidikan } & Frekuensi & Persentase(\%) \\
\hline Tidak Sekolah & 5 & $5,2 \%$ \\
SD & 16 & $16,5 \%$ \\
SMP & 33 & $34,0 \%$ \\
SMA & 39 & $40,2 \%$ \\
Perguruan & & \\
Tinggi & 4 & $4,1 \%$ \\
\hline Total & 97 & $100 \%$ \\
\hline
\end{tabular}

Tabel 4. Frekuensi Penghasilan

\begin{tabular}{lcr}
\hline \multicolumn{1}{c}{ Penghasilan } & Frekuensi & Persentase \\
\hline <500 Ribu & 8 & $8,20 \%$ \\
500 Ribu -1 Juta & 28 & $28,90 \%$ \\
1,1-2 Juta & 40 & $41,20 \%$ \\
>2 Juta & 21 & $21,60 \%$ \\
\hline Total & 97 & $100 \%$ \\
\hline
\end{tabular}

Tabel 5. Frekuensi Jarak Tempuh

\begin{tabular}{ccc}
\hline Jarak Relatif & Frekuensi & Persentase(\%) \\
\hline Sangat Jauh & 9 & $9,3 \%$ \\
Jauh & 30 & $30,9 \%$ \\
Dekat & 40 & $41,2 \%$ \\
Sangat Dekat & 18 & $18,6 \%$ \\
Total & 97 & $100 \%$ \\
\hline
\end{tabular}

\section{Analisis Data}

Pengujian hipotesis untuk mengetahui tingkat signifikansi secara bersama-sama pengaruh variabel independen terhadap variabel dependen menggunakan uji f. Analisis memakai SPSS version 16.0. Dari hasil analisis menggunakan uji f didapatkan bahwa kualitas pelayanan, usia, jenis kelamin, tingkat pendidikan, penghasilan dan jarak tempuh berpengaruh signifikan terhadap minat kunjungan ulang pasien (nilai signifikansi $0,000<0,01$ dan nilai $\mathrm{F}$ hitung lebih besar dari nilai $\mathrm{F}$ tabel 5,601>2,20). Pengujian hipotesis untuk menguji tingkat signifikasi secara 
Pengaruh Kualitas Pelayanan dan Karakteristik Sosiodemografi Terhadap Minat Kunjungan Ulang yang Dimoderasi Oleh Kepuasan Pasien Pada Pelayanan Rawat Jalan Puskesmas Kedungbanteng Kabupaten Banyumas

parsial apakah masing-masing variabel independen berpengaruh terhadap dependen menggunakan uji t. Analisis memakai SPSS version 16.0. Dari hasil analisis menggunakan uji t didapatkan sebagai berikut;

Tabel 5. Hasil Uji T

\begin{tabular}{lccc}
\hline \multirow{1}{c}{ Model } & \multicolumn{2}{c}{ Unstandardized } & \multirow{2}{*}{ Nilai } \\
& B & Std. & Sig. \\
& & Error & Sig. \\
\hline Kualitas Pelayanan & 0,920 & 0,288 & 0,002 \\
Kepuasan Pasien & 0,072 & 0,024 & 0,003 \\
Jenis Kelamin & 0,158 & 0,302 & 0,603 \\
Usia & $-0,678$ & 0,321 & 0,037 \\
Tingkat Pendidikan & $-1,980$ & 0,491 & 0,000 \\
Penghasilan & 1,553 & 0,487 & 0,002 \\
Jarak Tempuh & 0,175 & 0,306 & 0,568 \\
\hline
\end{tabular}

Dari tabel diatas variabel kualitas pelayanan memiliki nilai signifikansi $0,002(<0,05)$ dengan nilai B positif sehingga dapat disimpulkan bahwa kualitas pelayanan berpengaruh positif terhadap minat kunjungan ulang pasien. Variabel kepuasan pasien memiliki nilai signifikansi $0,003(<0,05)$ dengan nilai $\mathrm{B}$ positif sehingga dapat disimpulkan bahwa kepuasan pasien berpengaruh positif terhadap minat kunjungan ulang pasien. Variabel jenis kelamin memiliki nilai signifikansi $0,603 \quad(<0,05)$ sehingga dapat disimpulkan bahwa jenis kelamin tidak berpengaruh terhadap minat kunjungan ulang pasien. Variabel usia memiliki nilai signifikansi $0,037(<0,05)$ dengan nilai $\mathrm{B}$ negatif sehingga dapat disimpulkan bahwa usia berpengaruh negatif terhadap minat kunjungan ulang pasien. Variabel tingkat pendidikan memiliki nilai signfikansi 0,000 $(<0,05)$ dengan nilai $B$ negatif sehingga dapat disimpulkan bahwa tingkat pendidikan berpengaruh negatif terhadap minat kunjungan ulang pasien. Variabel penghasilan memiliki nilai signifikansi $0,002(<0,05)$ dengan nilai B positif sehingga dapat disimpulkan bahwa penghasilan berpengaruh positif terhadap minat kunjungan ulang pasien. Variabel jarak tempuh memiliki nilai signifikansi $0,568(>0,05)$ sehingga dapat disimpulkan bahwa jarak tempuh tidak berpengaruh terhadap minat kunjungan ulang pasien.

Pengujian hipotesis untuk menguji pengaruh interaksi kepuasan pasien sebagai variabel moderasi menggunakan uji MRA (Moderated Regression Analysis). Analisis memakai SPSS version 16.0. Dari hasil analisis MRA didapatkan sebagai berikut;

Tabel 6. Hasil Uji MRA

\begin{tabular}{llrl}
\hline \multicolumn{1}{c}{ Model } & \multicolumn{3}{c}{ Unstandardized } \\
& \multicolumn{2}{c}{ Coefficients } & Sig. \\
& B & S.Error & \\
\hline Jenis Kelamin-Kunjungan Ulang & $-0,437$ & 0,388 & 0,263 \\
Usia-Kunjungan Ulang & $-0,656$ & 0,396 & 0,101 \\
Pendidikan-Kunjungan Ulang & $-0,408$ & 0,318 & 0,203 \\
Penghasilan-Kunjungan Ulang & $-0,355$ & 0,317 & 0,266 \\
Jarak Tempuh-Kunjungan Ulang & $-0,803$ & 0,378 & 0,037 \\
Kualitas Pelayanan-Kunjungan Ulang & 1,525 & 1,886 & 0,421 \\
\hline
\end{tabular}


Dari tabel tersebut dapat diketahui bahwa pengaruh jarak tempuh terhadap minat kunjungan ulang yang dimoderasi oleh kepuasan pasien memiliki nilai signifikansi 0,037 (< 0,05), sehingga dapat disimpulkan bahwa keberadaan kepuasan pasien (sebagai variabel moderasi) dapat memperkuat atau memperlemah pengaruh jarak tempuh terhadap minat kunjungan ulang pasien rawat jalan Puskesmas Kedungbanteng.

Hal ini tidak berlaku untuk variabel jenis kelamin, usia, tingkat pendidikan, penghasilan, dan kualitas pelayanan dimana nilai signifikansi kepuasan pasien sebagai variabel moderasi $>0,05$, sehingga dapat disimpulkan bahwa kepuasan pasien tidak dapat memoderasi pengaruh jenis kelamin, usia, tingkat pendidikan, penghasilan, dan kualitas pelayanan terhadap minat kunjungan ulang pasien rawat jalan Puskesmas Kedungbanteng.

\section{Pengaruh Jenis Kelamin Terhadap Minat Kunjungan Ulang Pasien}

Berdasarkan hasil dari penelitian ini, jumlah responden paling banyak adalah perempuan 64 orang dan laki-laki 33 orang. Sedangkan hasil uji t menyebutkan bahwa tidak ada hubungan signifikan antara jenis kelamin dengan minat kunjungan ulang pasien (sig.>0,05). Dari data tersebut dapat disimpulkan bahwa perbedaan jenis kelamin tidak akan mempengaruhi naik turunnya minat kunjungan ulang pasien. Baik laki-laki ataupun perempuan sama-sama memanfaatkan fasilitas pelayanan kesehatan di Puskesmas Kedungbanteng dengan baik.

Mayoritas pengunjung di Puskesmas Kedungbanteng adalah perempuan. Hal ini sesuai dengan penelitian Putra (2010) bahwa faktor jenis kelamin merupakan salah satu faktor yang berpengaruh terhadap pemanfaatan layanan kesehatan karena dilihat dari tingkat kerentanan manusia yang bersumber dari jenis kelamin tersebut menjadikan tingkat pemanfaatan pelayanan kesehatan juga berbeda pada masing-masing jenis kelamin. Selain itu responden perempuan memiliki waktu lebih banyak dalam memperhatikan permasalahan kesehatan dibandingkan laki-laki yang harus bekerja untuk menafkahi keluarganya. Hal ini sejalan dengan teori yang dinyatakan oleh Fuchs, Dunlop dan Zubkoff dalam Laksono (2005) bahwa penggunaan pelayanan kesehatan oleh perempuan ternyata lebih tinggi daripada laki-laki karena perempuan memiliki insidensi terhadap penyakit yang lebih besar serta angka kerja perempuan yang lebih sedikit dari laki-laki membuat kesediaan dalam meluangkan waktu untuk pelayanan kesehatan menjadi lebih besar.

Meskipun perempuan paling banyak dalam pemanfaatan pelayanan kesehatan, hal ini tidak menutup kemungkinan untuk mereka berkunjung kembali ke layanan kesehatan tersebut. Hal ini sejalan dengan penelitian yang dilakukan oleh Ulfa (2012) bahwa loyalitas responden tidak berbeda pada jenis kelamin laki-laki maupun perempuan, sehingga jenis kelamin tidak mempengaruhi sifat loyal pasien.

\section{Pengaruh Usia Terhadap Minat Kunjungan Ulang Pasien}

Menurut Kotler (2009) faktor usia merupakan faktor penting yang perlu dipertimbangkan dalam strategi pemasaran. Setiap orang membeli barang atau jasa yang berbeda sepanjang hdupnya. Kebutuhan seseorang berkembang seiring bertambahnya usia sehingga kebutuhan, keinginan, dan harapan seseorang dipengaruhi oleh usia. Selaras dengan Notoatmodjo (2005) usia merupakan salah satu faktor yang dapat mempengaruhi pemanfaatan pelayanan kesehatan, kelompok usia muda (anak-anak) lebih rentan terhadap penyakit, usia produktif lebih cenderung berhadapan dengan masalah kecelakaan dan penyakit akibat gaya hidup, serta usia yang relatif lebih tua sangat rentan dengan penyakit kronis. 
Pengaruh Kualitas Pelayanan dan Karakteristik Sosiodemografi Terhadap Minat Kunjungan Ulang yang Dimoderasi Oleh Kepuasan Pasien Pada Pelayanan Rawat Jalan Puskesmas Kedungbanteng Kabupaten Banyumas

Rata-rata responden paling banyak yaitu pada kelompok usia 36-45 dan 46-55 tahun. Pada penelitian ini disebutkan juga bahwa usia berpengaruh negatif terhadap minat kunjungan ulang pasien. Hal ini dapat disimpulkan bahwa semakin berumur pasien semakin rendah minat kunjungan ulang pasien ke Puskesmas Kedungbanteng. Sejalan dengan hal tersebut, penelitian yang dilakukan oleh Hendrartini (1996) menunjukkan bahwa rata-rata kelompok umur dewasa muda (20-30 tahun) paling banyak memanfaatkan pelayanan kesehatan dibandingkan dengan kelompok yang lain. Hal ini dikarenakan dalam usia produktif mereka akan sangat rentan dalam kecelakaan dan lebih memperhatikan penampilan dibandingkan usia yang lebih matang. Selain itu, dalam penelitian Irawan dan Ainy (2018) menyebutkan bahwa usia berpengaruh signifikan terhadap pemanfaatan pelayanan kesehatan pada peserta Jamkesmas di wilayah Puskesmas Payakabung Kabupaten Ogan Ilir.

Dalam teori Patterson (2007) menyebutkan bahwa faktor usia dapat mempengaruhi tingkat loyalitas konsumen, pelanggan senior biasanya lebih konservatif, lebih jarang untuk mencoba merk lain dan cenderung lebih loyal. Sedangkan dalam penelitian ini disebutkan bahwa semakin berumur pasien semakin kurang minat kunjungannya terhadap puskesmas. Hal ini bisa terjadi karena semakin berumur pasien, semakin berkurang kekuatan fisiknya untuk mengunjungi Puskesmas yang terletak berjauhan dengan tempat tinggalnya sehingga mereka lebih banyak memanfaatkan Posyandu Lansia di desanya dalam pemeriksaan dan pengobatan kesehatannya.

\section{Pengaruh Tingkat Pendidikan Terhadap Minat Kunjungan Ulang Pasien}

Menurut Ihsan (2001) tingkat pendidikan adalah suatu tahapan pendidikan berkelanjutan yang didasari oleh tingkat perkembangan peserta didik dan tingkat kerumitan bahan ajar. Berdasarkan hasil penelitian ini, variabel tingkat pendidikan memiliki nilai signfikansi 0,000 $(<0,05)$ dengan nilai $\mathrm{B}$ negatif sehingga dapat disimpulkan bahwa tingkat pendidikan berpengaruh negatif terhadap minat kunjungan ulang pasien. Semakin tinggi tingkat pendidikan masyarakat semakin berkurang minat berkunjung kembali ke puskesmas.

Sejalan dengan teori yang dikemukakan oleh Barata (2006) semakin tinggi taraf pendidikan masyarakat semakin banyak pula tuntutan dan harapan mereka sehingga orang berpendidikan tinggi cenderung merasa tidak puas dibandingkan dengan orang yang berpendidikan rendah. Hal ini juga sesuai dengan teori yang dikemukakan oleh Syah dalam Chandra (2009) bahwa seseorang dengan tingkat pendidikan yang tinggi cenderung memiliki demand yang lebih tinggi daripada mereka yang berpendidikan rendah. Tingkat pendidikan akan berbanding lurus dengan tingkat pendapatan sehingga dengan pendidikan dan pendapatan yang tinggi mereka akan lebih kritis pada pelayanan yang mereka terima. Banyaknya puskesmas yang memiliki akreditasi paripurna dengan fasilitas yang lengkap dan pelayanan yang baik di setiap daerah masih dianggap sebelah mata karena adanya stigma negatif pada masyarakat bahwa puskesmas hanyalah pusat layanan kesehatan masyarakat kalangan bawah membuat masyarakat pendidikan tinggi berpikir ulang untuk memanfaatkan layanan tersebut.

\section{Pengaruh Pendapatan Terhadap Minat Kunjungan Ulang Pasien}

Pendapatan merupakan imbalan yang diterima oleh seorang konsumen dari pekerjaan yang dilakukannya untuk mencari nafkah (Sumarwan, 2002). Berdasarkan hasil penelitian ini, dapat diketahui bahwa mayoritas penghasilan responden adalah sekitar 1,1-2 juta per bulan sebanyak 40 responden dengan rata-rata pendapatan semua responden sebesar Rp 1.373.195,88.

Dalam Keputusan Gubernur Jawa Tengah No. 560/68 tahun 2018 menyebutkan bahwa upah minimum untuk Kabupaten Banyumas adalah sebesar Rp 1.750.000. Hal ini menggambarkan bahwa penghasilan minimal untuk dapat memenuhi kebutuhan dasar keluarga di Kabupaten 
Banyumas adalah Rp 1.750.000 per bulan. Sedangkan rata-rata penghasilan responden berada dibawah Upah Minimum Kabupaten (UMK) sebesar Rp 1.373.195,88. Hal ini tidak menurunkan minat kunjungan ulang responden dikarenakan seluruh responden merupakan peserta Jaminan Kesehatan Nasional (Jamkesnas) sehingga biaya pelayanan kesehatan masih terjangkau oleh responden. Hal tersebut sesuai dalam penelitian ini dimana dari data tabel 4.19 menyebutkan variabel penghasilan memiliki nilai signifikansi $0,002(<0,05)$ dengan nilai B positif sehingga dapat disimpulkan bahwa penghasilan berpengaruh positif terhadap minat kunjungan ulang pasien.

Penelitian ini sejalan dengan penelitian yang dilakukan oleh Hendrajani (2015) bahwa pendapatan berpengaruh signifikan pada kepuasan dan loyalitas konsumen Mustika Ratu di Madiun. Hal ini sesuai dengan teori yang dikemukakan oleh Tjiptoherianto (1994) bahwa orang yang memiliki pendapatan tinggi cenderung untuk menghabiskan uangnya untuk membeli berbagai barang dan jasa, sedangkan orang yang memiliki pendapatan rendah mempunyai keterbatasan dalam memenuhi pelayanan kesehatan karena tingginya biaya. Lumenta (1989) juga menyebutkan bahwa masyarakat yang berpenghasilan rendah pada umumnya sangat banyak yang bergantung pada fasilitas pelayanan kesehatan.

\section{Pengaruh Jarak Tempuh Terhadap Minat Kunjungan Ulang Pasien}

Berdasarkan hasil penelitian ini, variabel jarak tempuh memiliki nilai signifikansi 0,568 $(>0,05)$ sehingga dapat disimpulkan bahwa jarak tempuh tidak berpengaruh terhadap minat kunjungan ulang pasien. Hal ini dikarenakan kebanyakan responden memiliki jarak tempuh dekat dan sangat dekat dengan jumlah 58 orang dari 97 responden. Selain itu, dengan layanan transportasi dan akses menuju puskesmas yang terjangkau dapat memudahkan responden jarak jauh untuk memanfaatkan fasilitas puskesmas dengan baik. Dalam hal ini jarak tempuh bukan merupakan penghalang pasien untuk memanfaatkan fasilitas layanan kesehatan yang ada.

Menurut Akin dalam Tjahya dan Ghani (2010) jarak bukan merupakan faktor utama yang dapat mempengaruhi pemanfaatan pelayanan kesehatan. Hal ini sesuai dengan penelitian yang dilakukan oleh Intarti dan Khoriah (2018) bahwa tidak ada hubungan yang signifikan antara jarak tempuh dengan pemanfaatan Posyandu Lansia di wilayah kerja Puskesmas Cilacap Utara II. Sejalan pula dengan penelitian yang dilakukan oleh Suryandari (2013) bahwa tidak terdapat hubungan antara jarak tempuh dengan pemanfaatan Poskesdes pada masyarakat Desa Gawanan. Semakin dekat jarak rumah responden dengan layanan kesehatan tidak berdampak semakin tinggi pemanfaatannya oleh masyarakat.

\section{Pengaruh Kualitas Pelayanan Terhadap Minat Kunjungan Ulang Pasien}

Menurut Apriyanto dkk dalam Nasution (2018), pengukuran suatu kualitas pelayanan yaitu dengan mengetahui persepsi tentang pelayanan tersebut dari sudut pandang seorang konsumen atau pelanggan. Begitu pula dalam pelayanan kesehatan, yaitu dengan cara mengetahui penilaian tersebut dari persepsi pasien. Pada penelitian ini disebutkan bahwa variabel kualitas pelayanan memiliki nilai signifikansi $0,002(<0,05)$ dengan nilai B positif sehingga dapat disimpulkan bahwa kualitas pelayanan berpengaruh positif terhadap minat kunjungan ulang pasien. Apabila kualitas pelayanan meningkat maka minat kunjungan ulang pasien akan semakin tinggi.

Hal ini sejalan dengan penelitian dari Trimurthy (2008), bahwa terdapat hubungan antara persepsi pasien terhadap mutu pelayanan kesehatan dengan minat pemanfaatan ulang pelayanan rawat jalan di Puskesmas Pandanaran Kota Semarang. Penelitian oleh Kunto dalam Trimurthy (2008) juga menyatakan hal yang sama, dalam penelitiannya menyebutkan bahwa ada hubungan 
Pengaruh Kualitas Pelayanan dan Karakteristik Sosiodemografi Terhadap Minat Kunjungan Ulang yang Dimoderasi Oleh Kepuasan Pasien Pada Pelayanan Rawat Jalan Puskesmas Kedungbanteng Kabupaten Banyumas

yang bermakna antara persepsi pasien terhadap mutu pelayanan kesehatan yang terdiri dari bukti fisik, kehandalan, ketanggapan, jaminan, dan empati dengan minat pemanfaatan ulang pelayanan rawat inap umum di RS Kusta Kelet Jepara.

\section{Kepuasan Pasien Sebagai Variabel Moderasi}

Berdasarkan hasil penelitian ini dapat diketahui bahwa kepuasan pasien hanya dapat memoderasi pengaruh jarak tempuh terhadap minat kunjungan ulang dengan nilai signifikansi $0,037(<0,05)$, dan dapat disimpulkan bahwa keberadaan kepuasan pasien (sebagai variabel moderasi) dapat memperkuat atau memperlemah pengaruh jarak tempuh terhadap minat kunjungan ulang pasien rawat jalan Puskesmas Kedungbanteng. Sehingga meskipun jarak tempuh antara rumah pasien menuju puskesmas sangat jauh. Namun apabila pasien merasa puas dengan pelayanan yang diberikan oleh puskesmas, maka minat kunjungan ulang pasien akan meningkat.

Kepuasan pasien tidak dapat memoderasi pengaruh variabel lainnya seperti kualitas pelayanan, jenis kelamin, usia, tingkat pendidikan, dan pengasilan terhadap minat kunjungan ulang pasien. Hal ini dapat dilihat dari tabel 4.17 dimana nilai signifikansinya $>0,05$. Hal ini sejalan dengan penelitian yang dilakukan oleh Fauziah (2014) dimana kepuasan tidak dapat mempengaruhi hubungan antara kualitas produk dan loyalitas pelanggan, sehingga kepuasan tidak dapat bertindak sebagai variabel moderasi.

\section{KESIMPULAN DAN IMPLIKASI}

\section{Kesimpulan}

Berdasarkan hasil dan pembahasan diatas, maka dapat ditarik kesimpulan bahwa;(1) Kualitas pelayanan berpengaruh positif terhadap minat kunjungan ulang pasien. Hal ini menunjukkan bahwa semakin baik kualitas pelayanan puskesmas maka semakin tinggi pula minat kunjungan ulang pasien tersebut. (2) Jenis kelamin tidak berpengaruh terhadap minat kunjungan ulang pasien. Hal ini menunjukkan bahwa baik laki-laki ataupun perempuan tidak dapat menyebabkan tinggi rendahnya minat kunjungan ulang pasien tersebut. (3) Usia berpengaruh negatif terhadap minat kunjungan ulang pasien. Hal ini menunjukkan bahwa semakin tinggi usia pasien maka semakin rendah minat kunjungan ulang pasien tersebut. (4) Tingkat pendidikan berpengaruh negatif terhadap minat kunjungan ulang pasien. Hal ini menunjukkan bahwa semakin tinggi tingkat pendidikan pasien maka semakin rendah minat kunjungan ulang pasien tersebut. (5) Pendapatan berpengaruh positif terhadap minat kunjungan ulang pasien. Hal ini menunjukkan bahwa semakin besar pendapatan pasien maka semakin tinggi pula minat kunjungan ulang pasien tersebut. (6) Jarak tempuh tidak berpengaruh terhadap minat kunjungan ulang pasien. Hal ini menunjukkan bahwa jauh dekatnya jarak tempuh pasien tidak akan mebyebabkan tinggi rendahnya minat kunjungan ulang pasien tersebut. (7) Kepuasan pasien tidak dapat dapat memoderasi kualitas pelayanan, jenis kelamin, usia, tingkat pendidikan, dan penghasilan terhadap minat kunjungan ulang pasien. Hal ini menunjukkan bahwa besar kecilnya pengaruh kualitas pelayanan, jenis kelamin, usia, tingkat pendidikan, dan penghasilan terhadap minat kunjungan ulang tidak dapat diperkuat dengan adanya kepuasan pasien. (7) Kepuasan pasien dapat memoderasi jarak tempuh terhadap minat kunjungan ulang pasien. Hal ini menunjukkan bahwa pengaruh jarak tempuh pasien terhadap minat kunjungan ulang dapat diperkuat dengan adanya kepuasan pasien. 


\section{Implikasi}

Implikasi dari penelitian ini untuk akademik yaitu dapat menjadi acuan bagi akademisi mengenai pengaruh kualitas pelayanan dan karakteristik sosiodemografi terhadap minat kunjungan ulang pasien serta diharapkan untuk penelitian selanjutnya dapat melakukan penelitian dengan variabel moderasi yang lain. Sedangkan implikasi dari penelitian ini bagi pihak Puskesmas diantaranya yaitu; (1) Puskesmas senantiasa untuk selalu meningkatkan kualitas pelayanannya, khususnya pada aspek-aspek yang menjadi prioritas utama seperti kenyamanan ruang tunggu, pemberian informasi penyakit yang jelas, pemberian informed concent (informasi tindakan medis) yang jealas oleh petugas, pelayanan dokter, keterampilan petugas, kecepatan penanganan keluhan, dan sikap empati petugas dalam memberikan kesempatan pasien untuk menyampaikan keluhannya. Dengan adanya peningkatan kualitas pelayanan tersebut maka akan meningkatkan kepuasan pasien yang berdampak pada peningkatan minat kunjungan ulang pasien untuk berobat dan memeriksakan kesehatannya kembali di puskesmas. (2) Dalam rangka menaikan kunjungan ulang pasien Lansia, Puskesmas dapat memperbanyak jadwal penyelenggaraan Posyandu Lansia di setiap desa untuk mempermudah para Lansia dalam memeriksakan kesehatannya. (3) Untuk menarik calon pasien dari kalangan pendidikan tinggi Puskesmas dapat melakukan sosialisasi penyuluhan kesehatan yang lebih merata baik di tingkat pendidikan rendah maupun tingkat pendidikan tinggi karena tidak menutup kemungkinan dengan meningkatnya kualitas puskesmas akan meningkat pula kunjungan pasien dari kalangan pendidikan tinggi tersebut.

\section{DAFTAR PUSTAKA}

Alma, B., 2007, Manajemen Pemasaran dan Pemasaran Jasa, Bandung, CV Alfabeta.

Almana, L.O, Sudarmanto, Wekke, I.S., 2018, Tata Kelola Perguruan Tinggi Berbasis Akreditasi: Perjanjian Mutu dan Pengelolaan Pengetahuan di Pendidikan Tinggi, Sleman, Deepublish.

Azwar, A., 1996, Menjaga Mutu Pelayanan Kesehatan, Jakarta, Pustaka Sinar Harapan.

Azwar, A., 1999, Pengantar Administrasi Kesehatan, Jakarta, Binarupa Aksara.

Barata, A,A., 2006, Dasar-Dasar Pelayanan Prima, Jakarta, PT Elek Media Komputindo.

Bilson, S., 2001, Memenangkan Pasar dengan Pemasaran Efektif dan Profitabel. Jakarta, PT Gramedia Pustaka Utama.

Damanik, J. dan Helmut, F.W., 2006, Perencanaan Ekowisata dari Teori ke Aplikasi, Yogyakarta, PUSPAR UGM dan Andi.

Dharmawan, A., Dimas, N., dan Haryunanti, A.B., 2013, Analisis Faktor-Faktor Kualitas Pelayanan yang Mempengaruhi Kepuasan Penyetor Pajak di Kantor Pelayanan Pajak Madya Semarang, Informatika vol.1. No.1 hal: 11-23.

Fauziah, S., 2014 Pengaruh Kualitas Produk Terhadap Loyalitas Pelanggan dengan Kepuasan Sebagai Variabel Moderasi, Skripsi, Program Studi Manajemen Fakultas Ekonomi dan Bisnis Universitas Muhammadiyah Surakarta.

Hartono, B., 2010, Manajemen Pemasaran Untuk Rumah Sakit, Jakarta, Rineka Cipta.

Hendrajani, R., 2015, Pengaruh Pendapatan Terhadap Loyalitas dan Kepuasan Konsumen dengan Kualitas Produk Sebagai Variabel Mediasi Pada Pemakai Kosmetik Mustika Ratu di Madiun, Jurnal Manajemen Sumberdaya Manusia, Vol. 9 No.1 Hal: 62-71.

Hidajati, W., 2009, Hubungan Persepsi Kualitas Pelayanan Rawat Inap Kelas III RS Polpus Sukanto dengan Minat Memanfaatkan Ulang pada Pasien Dinas Tahun 2009, Thesis, Depok, FKM Universitas Indonesia. 
Pengaruh Kualitas Pelayanan dan Karakteristik Sosiodemografi Terhadap Minat Kunjungan Ulang yang Dimoderasi Oleh Kepuasan Pasien Pada Pelayanan Rawat Jalan Puskesmas Kedungbanteng Kabupaten Banyumas

Ihsan, F. (2001). Dasar-Dasar Kependidikan Cetakan Kedua, Jakarta, Rineka Cipta.

Intarti, W.D., dan Khoriah, S.N., (2018). Faktor-Faktor yang Mempengaruhi Pemanfaatan Posyandu Lansia, Journal of Health Studies, Vol.2 No.1 Hal:110-122.

Irawan, B., dan Ainy, A. (2018). Analisis Faktor-Faktor yang Berhubungan dengan Pemanfaatan Pelayanan Kesehatan Nasional di Wilayah Kerja Puskesmas Payakabung Kabupaten Ogan Ilir, Jurnal Ilmu Kesehatan Masyarakat, Vol 9(3) Hal:189-197.

Karyati, S.B. (2006). Analisis Pengaruh Persepsi Pasien tentang Mutu Pelayanan Dokter Spesialis Obstetri dan Ginekologi dengan Minat Kunjungan Ulang Pasien di Instalasi Rawat Jalan RSI Sultan Agung Semarang, Thesis, Semarang, Universitas Diponegoro.

Kotler . (2003). Marketing Management 11 Edition, New Jersey, Pearson Education.

Kotler, P., dan Keller, K.L. (2007). Marketing Management 12 Edition, New Jersey, Prentice Hall Int'l.

Li, M.H. (2010). The Influence of Perceived Service Quality on Brand Image, World of Mouth, and Repurchase Intention: A Case Study of Min-Sheng General Hospital in Taoyuan Taiwan, Journal of Marketing.

Lumenta, B. (1989). Pelayanan Medis, Citra, Konflik dan Harapan, Yogyakarta, Kanisius.

Ngai, E.W.T, Heung, V.C.S., Wong, Y.H., dan Chan, K.Y. (2007). Consumer Complaint Behaviour of Asians and Non Asians About Hotel Services, European Journal of Marketing, 41(11/12), hal: 13751391.

Notoatmodjo, S. (2005). Pendidikan dan Perilaku Kesehatan, Jakarta, Rineka Cipta.

Notoatmodjo, S. (2007). Kesehatan Masyarakat Ilmu dan Seni, Jakarta, Rineka Cipta.

Nuswantari, D. (1998). Kamus Kedokteran Dorland Edisi 25, Jakarta, EGC.

Patterson, P.G. (2007). Demographic Correlates of Loyalty in a Service Context, Journal of Service Marketing, Vo. 21 No.2 Hal:112-121.

Peraturan Menteri Kesehatan Republik Indonesia No.75 Tahun 2014 Tentang Pusat Kesehatan Masyarakat

PERMENKES RI No. 71 Tahun 2013 Tentang Pelayanan Kesehatan Pada Jaminan Kesehatan Nasional.

Phau, I., dan Baird, M. (2008). Complainers Versus Non-Complainers Retaliatory Responses Towards Service Dissatisfaction, Marketing Intelligence \& Planning, 26 (6), Hal: 587-604.

Putra, W. (2010). Analisis Permintaan Penggunaan Layanan Kesehatan pada Rumah Sakit Umum Milik Pemerintah di Kabupaten Semarang, Skripsi, Fakultas Ekonomi Universitas Diponegoro.

Rambat, L. dan Hamdani. (2001). Manajemen Pemasaran Jasa, Jakarta, Salemba Empat, hal.127.

Sarwono, S.W. (1996). Teori-Teori Psikologi Sosial, Jakarta, CV Rajawali.

Solikhah, 2008, Hubungan Kepuasan Pasien dengan Minat Pasien Dalam Pemanfaatan Ulang Pelayanan Pengobatan, Jurnal Manajemen Pelayanan Kesehatan, vol.11 no.4 hal: 192-199.

Sumarwan, U. (2002). Perilaku Konsumen: Teori dan Penerapannya dalam Pemasaran, Bogor, PT Ghalia Indonesia.

Suryandari, D. (2013). Hubungan Antara Faktor Jarak Pelayanan dengan Pemanfaatan Pos Kesehatan Desa di Desa Gawanan Kecamatan Colomandu, Prosiding Seminar Ilmiah Nasional Kesehatan, hal: 160-165.

Tjiptono. (2002). Strategi Pemasaran, Yogyakarta, ANDI.

Tjiptono, F. (2003). Strategi Bisnis, Yogyakarta,, ANDI, hal.7.

Tjiptono, F. (2008). Service Management Mewujudkan Layanan Prima, Bandung, Alfabeta.

Tjiptono, F. (2009) Service Marketing: Esensi dan Aplikasi, Yogyakarta, Marknesis.

Ulfa, R. (2012). Hubungan Karakteristik Pasien, Kualitas Pelayanan, dan Hambatan Pindah dengan Loyalitas Pasien di Instalasi Rawat Jalan Rumah Sakit Tugu Ibu Depok Tahun 2011, Tesis, 
Fakultas Kesehatan Masyarakat Program Studi Kajian Administrasi Rumah Sakit Universitas Indonesia, Depok.

Umar, H. (2003), Metode Riset Perilaku Konsumen Jasa, Jakarta, Ghalia Indonesia, hal.14.

UU No 36 Tahun 2009 Tentang Kesehatan.

Wade, C., dan Tavris, C., (2007), Psikologi Edisi 9 Jilid 2, Jakarta, Erlangga.

Yulianti, L.N., dan Anzola, Y.. (2009). Tingkat Kepuasan Konsumen Terhadap Tanggapan Perusahaan Pasca Tindakan Komplain Melalui Media Cetak, Jurnal Ilmu Keluarga dan Konsumen, 2(2), hal: 186-192.

Zeithaml, Valarie, A., and Bitner, Mary Jo., (2003). Service Marketing, New York, McGraw Hill Inc. 